\title{
Perspective
}

PERSPECTIVE Actualité en histoire de l'art

2| 2015

United States

\section{Did You Hear What They Said? Historicity and the present in the works by Adrian Piper and Renée Green}

\section{Elvan Zabunyan}

Translator. Olga Grlic

\section{(2) OpenEdition \\ Journals}

Electronic version

URL: http://journals.openedition.org/perspective/6012

DOI: $10.4000 /$ perspective. 6012

ISSN: 2269-7721

\section{Publisher}

Institut national d'histoire de l'art

\section{Electronic reference}

Elvan Zabunyan, « Did You Hear What They Said? Historicity and the present in the works by Adrian Piper and Renée Green », Perspective [Online], 2 | 2015, Online since 07 December 2015, connection on 01 October 2020. URL : http://journals.openedition.org/perspective/6012 ; DOI : https://doi.org/

10.4000/perspective.6012 


\title{
Did You Hear What They Said? ${ }^{1}$ Historicity and the present in the works by Adrian Piper and Renée Green
}

\author{
Elvan Zabunyan \\ Translation : Olga Grlic
}

On May 11, 2015, in Nantes, as a guest of honor at a ceremony commemorating the abolition of slavery, Angela Davis gave a lecture in which she stressed "the incessant repetition of history" and expounded on the methods that - since the ratification of the Thirteenth Amendment of the US Constitution in 1865 bringing about the legal end of slavery - have helped perpetuate racial discrimination and violence in the context of the prison-industrial complex in the United States. After five decades of activism, the American philosopher raises her voice with her usual clarity and firmness of tone. The rhythm of her sentences makes her vocal chords vibrate, giving volume to words that speak of the reality of racism. To listen to Davis is to be attuned to an unrivaled experience offered with knowledge and generosity, it is to shudder at the sound of this special pitch, it is to understand quite directly that, as she recalls in her speech, "most of the history of the United States is the history of slavery." Her arguments are incontrovertible: "if one assumes that slavery was really abolished in 1865 and that the arrival of the first slaves in the territories of the New World dates from 1619, that adds up to 266 years of legal bondage. Since it was abolished only 150 years ago, one could legitimately say that the greater part of the history of the United States is a history of slavery." ${ }^{2}$ This history of violence was largely continued with the establishment of "black codes" (followed by Jim Crow laws), which enabled the exploitation and restriction of freedoms by forcing emancipated slaves in the Southern states to work for miserable wages and condemning them to forced labor for minor offenses. According to Davis, this period of segregation, which persisted at least until the Civil Rights movement, is by no means over. She analyzes how the industrialization of the South in the late nineteenth century was achieved by replacing slave labor by that of 
prisoners. This system, based on the racial disparities in the US prison population, where the number of imprisoned young African Americans is disproportionately high conforms to the logic of economic profitability. This bridge between past and present is also evoked by the crimes and judicial blunders committed against a defenseless African American youth in a country that is nonetheless governed by the first African American president in its history. Ferguson still resonates, a year later, with the sound of the revolt that followed the death of Michael Brown. And the city is still, at this very moment, in a state of emergency. In Nantes, Davis offered a list of the victims of police violence since the Trayvon Martin case in 2012 that remained unpunished: Eric Garner, Tamir Rice, Jonathan Fersell, Eric Harris, Walter Scott, Freddie Gray,.... The list is not finished: the names of the nine people killed in the shootings of June 17, 2015 in the church in Charleston, South Carolina - a tragedy that confirms, yet again, the recurrence of racial violence - should be added to it.

On May 9, that is, two days before Angela Davis's talk, Adrian Piper won the Golden Lion at the $56^{\text {th }}$ Venice Biennale for her work, presented as part of All The World's Futures under the artistic direction of Okwui Enwezor. ${ }^{3}$ At the Arsenale, the artist exhibited an interactive installation (she also called it a "collective performance") entitled The Probable Trust Registry, The Rules of the Game \# 1-3 (2013-2015). Composed of three reception desks, above which were inscribed, three sentences in the first person singular, the work invite the visitors to participate in Piper's conceptual project by signing a document destined to join the archives of the Adrian Piper Research Archive Foundation based in Berlin, where it will be kept for a hundred years. ${ }^{4}$ This document requires the participant to confirm the statement that he or she has chosen. The first one declares: "I will always be too expensive to buy"; the second, "I will always mean what I say"; and the third, "I will always do what I say I am going to do." The first statement, understood in the context of an international event like the Venice Biennale, reflects the usual ethics of the artist, who created of and produced her work in a conceptual logic offering a direct critique of the art world. The other two refer to precepts advocating truth, whereas the "probable trust" of the installation's title unsettles certainties and demands from the participant an unbreakable commitment (to keep his or her promise), while also knowing that the context of art allows an escape from it through fiction. Piper's work has always sought to strike a balance between a narrative structure that juxtaposes the subjectivity of personal narrative and the objectivity of the reflective experience. As early as 1989, in her essay "Xenophobia and the Indexical Present," she reflected on her reasons for eliciting direct audience involvement in her works created since the late 1960s: "Because my creative commitment is inherently political, I am primarily motivated to do the work I do by a desire to effect concrete, positive, internal political change in the viewer, independently of - or in spite of - the viewer's abstract aesthetic evaluation of my work. I comfort myself with the thought that future generations of viewers, for whom the problems of racism and xenophobia will be less pressing and threatening, will surely provide the positive aesthetic evaluations I would like. Of course I'm always delighted when a present-generation viewer joins the ranks of eternity by expressing appreciation for my work now." ${ }^{5}$ When Piper wrote these lines, the United States was emerging from eight years of Reaganism. The lasting trauma of this presidency for people fighting for the most fundamental civil rights was confirmed in a country where social, economic, and cultural gains had been struck down. Hope seemed all the more futile once George H. W. Bush was elected. 
3 The wish that the artist expressed in that period is far from being fulfilled today in the context of the extreme violence that prevails, and her words now seem all the more insightful. Her disillusionment is unmistakable in the 2004 interview she granted to Dan Roediger: "American racism is frozen at the very elementary stage of denial and I don't think American society is capable of moving beyond that stage. Between about 1978 and 1992, I investigated and mapped this mindset in my work. After a while, I got bored, however, so I moved on." ${ }^{6}$ The ranks of eternity evoked by Adrian Piper are expressed in her Venice installation through proposal to archive spectators' promises for a century.

4 These promises are also applied to herself since we see her (in the documentation on her website) ${ }^{7}$ sign the three iPads used to digitally record the tacit commitment between the participant and the research foundation. This virtual space is particularly rich for understanding the high standards that Adrian Piper brings to bear daily on work. On the home page, we discover a work that she created in 2013, which can be freely downloaded. ${ }^{8}$ This work shows the evanescent face of Trayvon Martin on which is printed a red target. Imagine (Trayvon Martin) bears a blue typewritten inscription, modeled on the characteristic font artist's work since the 1970s, that reads: "Imagine what is was like to be me." Only the "me" extends beyond the frame, set against a black border that enhances the effect of a death announcement. Piper's relationship to current events and to the possibility of conceptualizing the present is particularly visible in the way her website is managed. It is located at the crossroads of a radical analysis of an American society based on racial injustice and a relentless readjusting that the artist makes despite the inadequate reception of her artistic and philosophical project that she refuses to see categorized by specialized media.

5 All of her work is rooted in an analysis that occurs beyond the dichotomy of the colors black and white. Furthermore, her theoretical contribution to the history of contemporary art is articulated in relation to a research whose origins lie in conceptual art. This form has served as touchstone for her creative method since her earliest work in 1960s and allows her to cast a fierce look on everything that reflects to racial stereotypes. Again, as she recalled in her 1989 essay, "I want viewers of my work to come away from it with the understanding that racism is not an abstract, distant problem that affects all those poor, unfortunate other people out there. It begins between you and me, right here and now, in the indexical present."

6 If the portrait of the murdered young raises the questions of disappearance captured in its visual and metaphorical reality (the fading of the figure, death), the issue of what is likely to disappear has been a central to Adrian Piper's work since 2003, starting with her series Everything. This is the first word of a sentence that serves as a point of departure: Everything will be taken away. In the part of the Biennale exhibition located in the International Pavilion at the Venice Giardini, the phrase, written in chalk, is repeated on several school children's blackboards. The erasure intrinsic to the materials used tends to affirm that the loss implied in the removal of this "everything" is, or may be, imminent. "Everything will disappear, will be removed, will be taken" if... one might add, thinking of the repetition of history within a frustrated continuity. The conditional would therefore confirm that the future we are expecting is that of a tabula rasa. Dissolving the words "Everything will be taken away" became a performance at Piper's exhibition in Scotland in $2010 .{ }^{10}$ One hundred sentences that covered four blackboards on the surface of one wall are carefully erased, but, even when gone, they 
are preserved by memory. They seem suspended in time, waiting to be seized by the materiality of words to come that resonate in order to resist.

7 We have already established that politics is at the heart of Adrian Piper's work, but her work is also closely associated with yoga, which she has been practicing since 1965. As a discipline that strengthens the body and the mind, yoga facilitates a renewed relationship with the other, and in a very different way than that encountered in the Western world. One's own well-being is necessarily inscribed in the relation to the space that one occupies with others. Yogic breathing is the source of life and its light. The confrontation with one's own image, interlaced with otherness, as Piper proposes in her exhibition Everything in New York in 2008 - whereupon entering viewers see their reflection in a mirror on which is engraved in gold letters "Everything will be taken away" - is a way to split and at the same time consolidate the body. ${ }^{11}$

What matters here is the critical discernment that is necessary in order to understand the notion of belonging to an identity that exists first and foremost through our own gaze, rather than that imposed by others on the subject that we are. By eliminating stigmatization as "white" and "black" ("'black' and 'white' are among the terms my work critiques," stresses the artist) ${ }^{12}$ she rejects the essentialist definition of cultural identity. Eschewing categorization by proposing the development of a theoretical thought, of an artistic reflection, and of political protest that rely both on the rigor of Kantian philosophy (in which she specializes) and on a being-in-the-world that is bestowed by yoga, she becomes elusive while being perfectly in tune with the world in the present that she has decided to resist. Within art history, art criticism, and museums, which tend to standardize artistic practices of the most radical artists in order to reterritorialize them, the tools proposed, no matter how squeaky they are, serve to decompartmentalize. Conceptual reasoning is the foundation for a philosophy of life that echoes singular artistic processes, as Adrian Piper recounts with respect and humor in her homage to Sol LeWitt, who was a close friend: "He said I was turning people's races into stacked cubes, I said he had turned stacked cubes into human beings." ${ }^{13}$ The rigidity of uncompromising conceptual art softens when its reading is no longer directed by codes imposed by the academy or the art market.

In her work Everything, presented in New York, Adrian Piper exposed viewers to their own image and also to a video loop showing CNN coverage of a sordid 2007 news event of a young African American woman who reported being tortured by six people in West Virginia. ${ }^{14}$ In another room, the artist presented works she had made based on images from Hurricane Katrina. Partially erased photographs of destroyed homes and devastated landscapes repeatedly give way to the phrase "Everything will be taken away." This sentence here confirms the historical reality to which it refers and the pitiful government response to this unprecedented hurricane in the United States, as the artist emphasizes her anger at the disaster and the inhuman social and racial injustices that struck hundreds of thousands of survivors in one of the poorest Southern states in the country at the end of August 2005.

Adrian Piper's working method and the research she conducts in producing her multimedia installations rely on visual, audiovisual, and sound archives in order to stay as close as possible to current events, emphasizing the way the media treat violent incidents, especially in their repetition during television rebroadcasts. Black Box, White Box, an installation she conceived in response to the invitation by the Wexner Center for the Arts in Columbus, Ohio for the exhibition Will/Power in 1992, examines the 
media reality of the Rodney King beating that happened on March 3, 1991 and the riots that followed in the spring of 1992 in Los Angeles after the verdict that declared the four policemen accused of violence against the young man not guilty. ${ }^{15}$ Two cubes contain, respectively, elements referring to the King case where the spectators who enter can read this quote by Alexander Solzhenitsyn: "Once you have taken everything from a man, he is no longer in your power. He is free." This is the first time the artist used the sentence that would become the declarative foundation of her "Everything will be taken away" series. We thus comprehend the bitter duality between freedom and one's loss of it through the power that Piper projects onto the violence perpetrated against Rodney King but also, by extension, suffered by millions of men and women since the era of slavery in the United States. The possibility of being free because of being dispossessed is as much a political as an ethical reflection. The amateur video of beating by George Holliday, which runs in a loop in the white cube, is accompanied by the song What's Going On? by Marvin Gaye, composed in 1971 when his brother was drafted into the Vietnam War. The portrait of Rodney King with his swollen face is in the black cube, opposite an image of President Bush shaking hands with the acquitted policemen. Two experiences, where the power of images in the context of an artistic and aesthetic project, bring together archives, history, present. ${ }^{16}$

11 The historiography coming out of the study of certain exhibitions organized by artists in the early 1990s, taking into account the connection between archives and historicity regularly draws on writings produced by the artists themselves. Renée Green is undoubtedly one of the artists whose work and critical output share Adrian Piper's arguments and her exactitude. In 2004, she noted, "Fredric Jameson wrote 'Periodizing the 60s' in 1984. Perhaps it will be possible to describe the 90 s and the early 21 st century better in 24 years. Attempting to do so at this moment can allow for descriptions and attempts at analysis, but these can be compared in advance with the versions of 'history in the making' of many previous times." ${ }^{17}$ Published at the end of 2014, an anthology of her writings entitled Other Planes of There is built in a rhizomic form that intertwines various periods of her work. On the back cover we find an image of her installation Sites of Genealogy (1991), exhibited for ten months at PS1 Contemporary Art Center in New York. The top floor of the art center was transformed by the artist in a way to suggest the attic in which, for seven years, Harriet Jacob hid while fleeing slavery. Her autobiography, published in 1861 under the name Linda Brent, contains a chapter "The Loophole of Retreat" that gives its name to the work in progress that Green conceived for PS1. ${ }^{18}$ The artist's wish to "close" her own book with an image of that work in particular is not coincidental, given how much she is interested in American racial history while asserting, just like Adrian Piper, the importance of transcending the stereotyped categories of "white" and "black."

At the same moment that her writings, juxtaposing a multitude of references to contemporary intellectual, artistic, and literary history, and supplemented by more personal working notes and interviews, appeared in print, Renée Green was also working on her exhibition Begin Again, Begin Again at the Schindler House in Los Angeles. This work once again underscores her meticulous attitude to research. ${ }^{19}$ She chose to exhibit the proofs of her book in a showcase, like so many pages evoking the process of creating an idea. The works seem to be extensions of conceptual arguments she lays out in Other Planes of There. Bringing out several of her older works, as well as those made specifically for this project - including the video Begin Again, Begin Again. I. 1887-1929 (2015), a spatial poem Space Poem \# 5 (Years \& Afters) (2015), and the sound 
piece Begin Again, Begin Again (Circulatory Sound) (2015), - the exhibition questions, right from the title, the relation to history and to memory.

However, it is probably in indexing the present that Renée Green's artistic, theoretical, and poetic intentions come together most clearly. And although if we can read "Within Living Memory" on one of the prints presented in the exhibition, the immediate present is also invoked. She concludes her introductory essay for Other Planes of There with a postscript, a tribute to two American artistic figures who have sought, through their work, a critical reception of their cultural identity "Jimmie Durham lives in Europe, and it is said that he will not return to the United States. The same is said of Adrian Piper. I hope they live happily ever after." ${ }^{20}$ Over twenty years ago, Jimmie Durham wrote, "If we do not remember the past, are we condemned to repeat it? If the past is history, how can we remember it?" ${ }^{21}$ Here the artists are those who enable art history to be written. Their artistic creation allows chronology to unfold from the past towards an infinite future, and vice versa, allows the date to settle, but also to escape, allows eternity to join the present. Their freedom is limitless.

\section{NOTES}

1. "Did you hear what they said?" is the title of a piece composed by the poet and musician Gil Scott-Heron for his album Free Will that came out in 1972. In it he evokes police violence that found echo in the recent events in the United States.

2. Davis's lecture can be listened to on this site: http://the-dissident.eu/6414/angela-davislindustrie-carcerale-aux-etats-unis-nest-que-le-prolongement-de-lesclavage (viewed on October 20, 2015).

3. It may be necessary to specify that the structure of this article was designed from a very rigorous plan that privileges the relationship between historicity and current events. Highlighting the temporal links between different events, the critical work of the cited personalities on the consequences of racial discrimination in the United States has been invoked. Respecting Adrian Piper's principle of no longer seeing herself as "black" in order to guarantee the absence of essentializing and stereotyped racial categorization, I have decided not to mention at any time Angela Davis's, Adrian Piper's or Renée Green's skin color. For Piper's position, see the biographical note in La Biennale di Venezia: 56th International Art Exhibition, All the World's Futures, Okwui Enwezor, Luz Gyalui eds, (exh. cat., Venice, Biennale, 2015), Venice, 2015, p. 593: "In 2012, Piper publicly announced her retirement from being black." From an epistemological point of view, it is obvious that it is not within the scope of this article to erase what would be "black." It is rather to introduce a paradigm shift by privileging a critique of racism based on authoritarian foundations of racial discrimination and not on what the terminology itself imposes as a definition of this qualifying adjective. The words and forms produced by artists and intellectuals are enough to counter this criticism without the need to specify the "black" or "white" character of the authors.

4. For the instructions for the work and its detailed description, see the artist's website: www.adrianpiper.com (viewed on October 20, 2015).

5. Adrian Piper, "Xenophobia and the Indexical Present" (lecture, 1989), in Adrian Piper, Out of Order: Out of Sight, I, Cambridge (MA), 1996, p. 248. 
6. Dan R. Roediger, "Mapping Mindsets: A Conversation with Adrian Piper," in Art Papers Magazine, 28/5, September-October 2004, p. 37.

7. http://www.adrianpiper.com/art/biennale/index.shtml (viewed on October 20, 2015).

8. http://www.adrianpiper.com/art/index.shtml (viewed on October 20, 2015).

9. Piper, 1996, cited n. 5, p. 248.

10. Everything \# 21, 2010-2013, the installation presented at the Cairn Gallery in Scotland was erased at the end of the exhibition by Laurie Clark, an action considered by Adrian Piper as the "final performance."

11. The exhibition was presented at the Elizabeth Dee gallery in March-April, 2008. See the review by Kirsten Swenson in Art in America, 96/6, June-July, 2008, p. 194-196.

12. Adrian Piper, "It's Not All Black and White," letter to the editor, in Village Voice, June 9, 1987, p. 6. This quote is repeated by John P. Bowles in "Adrian Piper as African American Artist," in American Art, 20/3, Fall 2006, p. 108. This article has been reprinted in the introduction of his book: John P. Bowles, Adrian Piper: Race, Gender, and Embodiment, Durham/London, 2011, p. 1.

13. See www.adrianpiper.com/art/sol.shtml (viewed on October 20, 2015).

14. Megan Williams reversed her testimony in 2009, with drawing her accusation in the case of five of the six presupposed defendants.

15. The exhibition Will/Power was organized as part of the celebrations for the five hundredth anniversary of the discovery of America by Christopher Columbus, but the curators' aim was to produce an analysis against the tide of conventional celebrations by inviting artists to examine the history of United States in a critical fashion. See, Will/Power: New Works by Papo Colo, Jimmie Durham, David Hammons, Hachivi Edgar Heap of Birds, Adrian Piper, Aminah Brenda, Lynn Robinson, Sarah J. Rogers-Lafferty ed., (exh. cat., Columbus, Wexner Center for the Arts, The Ohio State University, 1993), Columbus, 1993.

16. For a detailed analysis of the Black Box/White Box installation, revisited in the context of September 11, 2001 and as part of Adrian Piper's traveling retrospective exhibited at the New Museum in New York (October 4, 2001-13 January 2002) as well as the artist's lecture in Greensboro in November 2001, see Francis Frascina, "Class, Conflict, Race and Remembrance: Adrian Piper's Black Box/White Box, Greensboro (NC), November 1, 2001," in Oxford Art Journal, 28/1, 2005, p. 1-24 .

17. Renée Green, “Other Planes of There" (2004), in Renée Green, Other Planes of There: Selected Writings, Durham/London, 2014, p. 165.

18. Linda Brent, Incidents in the Life of a Slave Girl, (Boston, 1861) San Diego/New York, 1973, see, in particular, chapter XXI, "Loophole of Retreat," p. 117-120.

19. The exhibition Begin Again, Begin Again took place from January 21 to March 29, 2015, at the MAK Center for Art and Architecture of the Schindler House (Los Angeles).

20. Green, 2014, cited n. 15, p. 13. As stated in Adrian Piper's biography in the catalogue of the Venice Biennale, it is when she learned that she appears as a "suspicious traveler" on the US Transportation Security Administration list that she decided stay in Berlin rather than return to the United States. See La Biennale di Venezia, 2015, cited n. 3, p. 593.

21. Jimmie Durham, “To Be a Pilgrim: Walton Ford," in Artforum, 30/5, January 1992, p. 60. 
INDEX

Keywords: contemporary art, American cultural history, American political history, memory, slavery

Mots-clés: art contemporain, histoire culturelle américaine, histoire politique américaine, mémoire, esclavage

Geographical index: États-Unis

Chronological index: 1900,2000

\section{AUTHORS}

\section{ELVAN ZABUNYAN}

Université Rennes 2 